\title{
İdiyopatik Nefrotik Sendromda İlk Atakta Steroid Bağımlılığı Öngörülebilir mi?
}

\section{Could Steroid Dependency Be Predicted at the First Attack in Idiopathic Nephrotic Syndrome?}

\section{Aysel Taktak ${ }^{1}$ (D), Neslihan Çiçek ${ }^{2}$ (D)}

${ }^{1}$ Mustafa Kemal Üniversitesi, Tayfur Ata Sökmen Tıp Fakültesi, Çocuk Nefrolojisi, Hatay, Türkiye ${ }^{2}$ Marmara Üniversitesi, Tıp Fakültesi, Çocuk Nefrolojisi, İstanbul, Türkiye

ORCID ID: A.T. 0000-0001-7724-9160; N.Ç. 0000-0002-5859-4177

Atıf/Citation: Taktak A, Cicek N. İdiyopatik nefrotik sendromda ilk atakta steroid bağımlılığı öngörülebilir mi? Çocuk Dergisi - Journal of Child 2020;20(3):96-99. https://doi.org/10.26650/jchild.2020.3.807529

öz

Amaç: İdiyopatik nefrotik sendrom (iNS) çocuklarda en sık görülen glomerüler hastalık olup, \%80'i steroide duyarlıdır. Steroide duyarlı nefrotik sendrom (SDNS) hastalarının yaklaşık yarısı steroid bağımlı nefrotik sendromudur (SBNS). Bu çalışmanın amacı ilk atağında başvuran SDNS hastalarında, steroid bağımlıı̆ı̆ı tedavi öncesi öngörebilecek risk faktörlerini belirlemektir.

Gereç ve Yöntem: Çocuk Nefroloji Kliniğimize Eylül 2016-Eylül 2018 tarihleri arasında ilk atak iNS ile başvuran ve steroid tedavisine yanıtlı hastalar geriye dönük olarak değerlendirildi. Hastaların demografik özellikleri, poliklinik kan basıncı ölçümü, kan albümin ve kreatinin değeri, beyaz küre sayısı, lenfosit sayısı, lenfosit/beyaz küre oranı, spot idrar protein/kreatinin oranı, steroid tedavisi başlanmasını takiben remisyona girme süresi ve atak başlatıcısı kaydedildi.

Bulgular: Hastaların 23'ü SDNS, 16'sı SBNS tanısı aldı. Başvuru yaşı ortalaması SDNS grubunda $77,34 \pm 32$ ay, SBNS grubunda $73,62 \pm 27,32$ ay idi $(p=0,690)$. Iki grup arasında kan albümin, kreatinin, lenfosit sayısı ve lenfosit/beyaz küre oranı açııından anlamlı fark saptanmadı. Atak başlatıcısı SBNS grubunda daha fazla görüldü $(p=0,001)$ ve en sık tespit edilen atak başlatıcısı üst solunum yolu enfeksiyonu idi. Spot idrar protein/kreatinin oranı, kan beyaz küre seviyesi SBNS grubunda anlamlı yüksek saptandı $(p=0,014, p=0,004)$ ve remisyona girme süresi SBNS grubunda daha uzundu (17,5 güne 9 gün) ( $p=0,000)$.

Sonuç: İdiyopatik NS'de, üst solunum yolu enfeksiyonuyla ilk atağın tetiklenmesi, başvuru anında ağır proteinüri saptanması ve geç remisyona girme süresi SBNS gelişmesi açııından risk faktörleri olabilir. Bu hastalarda steroid ayıııc tedavilerin daha erken gündeme alınması, steroid tedavisinin istenmeyen uzun dönem yan etkilerinden koruyacaktır.

Anahtar Kelimeler: Nefrotik Sendrom, steroid tedavisi, steroid bağımlı nefrotik sendrom, çocuk

\section{ABSTRACT}

Objective: Idiopathic nephrotic syndrome (INS) is the most common glomerular disease in children. Approximately $80 \%$ of INS is steroid sensitive (SSNS), and half of SSNS patients are steroid dependent (SDNS). This study determines the risk factors that may predict steroid dependence in patients with SSNS.

Material and Method: Patients with SSNS who followed in our Pediatric Nephrology clinic between September 2016 and September 2018 were retrospectively evaluated. The demographic characteristics, albumin, creatinine values, blood pressure, white blood cell, lymphocyte count, lymphocyte/white blood cell ratio, urine protein-creatinine ratio, time to remission, and triggers of the attack were recorded.

Results: Twenty-three patients were diagnosed as SSNS and 16 as SDNS. The mean age at presentation was $77.34 \pm 32$ months in the SSNS group and $73.62 \pm 27.32$ months in the SDNS group $(p=0.690)$. No significant difference was observed between the two groups in terms of blood albumin, creatinine, lymphocyte count, and lymphocyte/white blood cell ratio. Trigger initiating the attack was more common in the SDNS group $(p=0.001)$. The most common trigger was upper respiratory tract infection. Urine protein/creatinine ratio and white blood cell levels were significantly higher in the SDNS group ( $p=0.014, p=0.004$, respectively), and the time to remission was also longer in the SDNS group $(p=0.001)$.

Conclusion: Upper respiratory tract infection may be a trigger, and severe proteinuria and late remission time may be risk factors for the development of SDNS in INS. Early use of steroid-sparing agents in these patients can prevent long-term adverse effects of steroid therapy.

Keywords: Nephrotic syndrome, steroid treatment, steroid depended nephrotic syndrome, child

Sorumlu Yazar/Corresponding Author: Aysel Taktak E-mail: aysel.taktak@gmail.com

Başvuru/Submitted: 10.08.2020 • Revizyon Talebi/Revision Requested: 04.09.2020 • Son Revizyon/Last Revision Received: $15.09 .2020 \bullet$ Kabul/Accepted: 03.11.2020 


\section{Giriş}

Nefrotik sendrom (NS) masif proteinüri, hipoalbüminemi, ödem ve hiperlipidemi ile karakterize klinik bir tablodur (1). İdiyopatik NS (iNS) ise nefrotik sendrom ve spesifik olmayan histopatolojik bulguların birlikteliği olarak tanımlanır. Bu histopatolojik bulgular, minimal değişiklik hastalığı (MDH), fokal segmental glomerüloskleroz (FSGS) ve diffüz mezengiyal proliferasyon (DMP) şeklinde olabilir. Çocukluk çağında görülen NS'ların \%90'ı iNS'dir (2). Nefrotik sendrom tedavisinde temel hedef proteinürinin ortadan kaldırılması veya mümkün olan en düşük seviyeye getirilmesidir, bu amaçla tedavide kullanılan ilk seçenek steroidlerdir. İdiyopatik NS'de prognoz altta yatan histopatolojik bulgu ve steroid tedavisine yanıt ile yakından ilişkilidir. Çocukluk çağı iNS'lerinin \%80'i steroid tedavisine yanıtlıdır, ancak steroide duyarlı NS (SDNS) hastalarının yaklaşık \%70'inde tedavi kesimi sonrası ilk 12 ayda relaps gelişir. Hastaların yaklaşık \%50'sinde ise steroid bağımlı NS (SBNS) görülür $(1,3)$. Bu hastalar yüksek doz ve uzun süre steroid tedavisinin olası yan etkileri olan Cushing sendromu, hipertansiyon, hiperlipidemi, hiperglisemi, enfeksiyonlar ve büyüme geriliği gibi ciddi sorunlar açısından risk altındadır (4). Steroid bağımlı NS hastalarının erken tespit edilmesi, bu hastalarda vakit kaybedilmeden steroidden kurtarıcı tedavilerin başlanması, hastaların renal sağ kalımlarına olumlu etki etmenin yanı sıra uzun süre, yüksek doz steroid tedavisinin istenmeyen yan etkilerinden de koruyacaktır.

Bu çalışmanın amacı ilk atak ile başvuran steroid tedavisine yanıtlı iNS hastalarında, steroid bağımlılığını tedavi öncesi öngörebilecek risk faktörlerini belirlemektir.

\section{GEREÇ VE YÖNTEM}

Çocuk Nefroloji Kliniğimize Eylül 2016-Eylül 2018 tarihleri arasında ilk atak iNS ile başvuran ve steroid tedavisine yanıtlı hastalar geriye dönük olarak değerlendirildi. Çalışmaya alınan hastaların yaş, cinsiyet, kan basıncı, başvuru anında kan albümin değeri, kan kreatinin değeri, lenfosit sayısı, beyaz küre sayısı, lenfosit/beyaz küre oranı, spot idrar protein/kreatinin oranı, steroid tedavisi başlanmasını takiben remisyona girme süresi,
SBNS olup olmadığı ve tüm hastalarda atak başlatıcısı kaydedildi. Klinik olarak ödem, proteinüri (spot protein/kreatinin $>2$ ), hipoalbüminemi (kan albümin $<2,5 \mathrm{~g} / \mathrm{dL}$ ) olan hastalar NS olarak değerlendirildi. İkincil nefrotik sendromu düşündürecek hikâye, fizik bakı ve laboratuvar sonucu olan hastalar çalışmaya dâhil edilmedi. Steroid tedavisi başlanmasını takiben birbirini izleyen üç gün idrar daldırma çubuğu ile proteinürinin eser/ negatif olması ve kan albümin değerinin $\geq 2,5 \mathrm{~g} / \mathrm{dL}$ olması remisyon olarak değerlendirildi. Steroid tedavisi gün aşırı iken ve/ veya tedavi kesimini takiben 14 gün içerisinde en az 2 relaps olan hastalar SBNS olarak tanımlandı (2). Tüm hastalarda steroid tedavisi $2 \mathrm{mg} / \mathrm{kg} / g u ̈ n$ (en fazla $60 \mathrm{mg} / g u ̈ n$ ) olacak şekilde dört hafta tam doz verildi. Daha sonra $1,5 \mathrm{mg} / \mathrm{kg} /$ gün günaşırı doza geçildi ve kademeli olarak azaltılarak beş aya tamamlandı. Günaşırı steroid tedavisi altında olup relaps gelişen SBNS hastalarında tedavi remisyon sağlanıncaya kadar günlük olarak verildi ve daha sonra azaltılma şeması uygulandı.

Çalışma Helsinki Bildirisine uygun yerel etik kurulca 24/09/2020 tarihli 11 numaralı toplantida 15 numaralı karar ile onaylanmıştır.

\section{İstatiksel Analiz}

İstatistiksel analiz için Statistical Packages for the Social Sciences (SPSS Inc. Chicago, IL, USA)programı 21.0 versiyonu kullanıldı. Verilerin dağılım homojenitesi Kolmogorov-Smirnov testi ile değerlendirildi. Normal dağılım gösteren veriler ortalama standart sapma, normal dağılıma uymayan veriler ortanca (çeyrekler arası aralık-ÇAA) olarak verildi. Normal dağılım gösteren verilerin karşılaştırılmasında t-test, normal dağılım göstermeyen verilerin karşılaştırılmasında Mann-Whitney-U testi uygulandı. $p<0,05$ değeri istatistiksel olarak anlamlı kabul edildi.

\section{BULGULAR}

Bu çalışmada iNS tanısı konulmasını takiben en az bir yıl süreyle izlenen 39 hasta değerlendirildi. Yirmi üç hasta (\%59) SDNS 16 (\%41) hasta ise SBNS tanısı almışt. SDNS grubunu oluşturan hastaların 12 'si erkek $(\% 52,2) 11^{\prime}$ i kızdı $(\% 47,8)$. SBNS grubunu oluşturan hastaların ise $11^{\prime} i$ erkek $(\% 68,8)$ 5'i kızdı $(\% 31,2)$, her

Tablo 1: Çalışmaya alınan hastaların demografik özellikleri ve laboratuvar sonuçları.

\begin{tabular}{|c|c|c|c|}
\hline & SDNS $(n=23)$ & SBNS $(n=16)$ & $p$ \\
\hline Cinsiyet n (\%) & & & 0,300 \\
\hline Erkek & $12(\% 52,2)$ & $11(\% 68,8)$ & \\
\hline Yaş (ay) & $77,34 \pm 32$ & $73,62 \pm 27,32$ & 0,69 \\
\hline Atak tetikleyici faktör & & & 0,001 \\
\hline Var & $2(\% 8,7)$ & $9(\% 56,3)$ & \\
\hline Yok & $21(\% 91,3)$ & $7(\% 43,7)$ & \\
\hline Serum albümin (g/dL) & $1,55 \pm 0,48$ & $1,49 \pm 0,53$ & 0,71 \\
\hline Serum kreatinin (mg/dL) & $0,39 \pm 0,08$ & $0,40 \pm 0,07$ & 0,56 \\
\hline Lenfosit/BK & $0,42 \pm 0,10$ & $0,35 \pm 0,15$ & 0,149 \\
\hline Kan lenfosit $\left(\mathrm{mm}^{3}\right)$ & 3440 & 3315 & 0,96 \\
\hline Kan beyaz küre $\left(\mathrm{mm}^{3}\right)$ & 7600 & 9720 & 0,004 \\
\hline İdrar protein/kreatinin & $7,57 \pm 4,53$ & $12,39 \pm 6,27$ & 0,014 \\
\hline Remisyone girme (gün) & 9 & 17,5 & 0,001 \\
\hline
\end{tabular}

SDNS: Steroide duyarlı nefrotik sendrom, SBNS: Steroide bağımlı nefrotik sendrom, BK:beyaz küre. 
iki grup arasında cinsiyet dağılımı açısından anlamlı fark görülmedi $(p=0,300)$. Steroide duyarlı NS grubunda yaş ortalaması $77,34 \pm 32$ ay iken SBNS grubunda yaş ortalaması $73,62 \pm 27,32$ aydı $(p=0,690)$. Çalışmaya alınan her iki grup atak başlangıcı kan albümin, kan kreatinin değerleri, kan lenfosit sayısı, lenfosit/beyaz küre oranı açısından karşılaştırıldığında anlamlı fark görülmedi. Atak başlatıcısının olup olmaması açısından karşılaştırıldığında SBNS hastalarında anlamlı şekilde tetikleyici faktör olduğu görüldü ( $p=0,001)$. Steroide duyarlı NS hastalarının ise \%91,3'ünde öykü ve fizik muayene ile tetikleyici bir unsur tespit edilmedi. Tetikleyici faktör olarak en sık tespit edilen durum üst solunum yolu enfeksiyonu (ÜSYE) $(n=6)$ idi. Diğer tetikleyiciler aşı $(n=1)$ ve travma sonrası kol kemiğinde kırık $(n=2)$ idi. Çalışmaya alınan tüm hastalarda teknik nedenlerle 24 saatlik idrar çalışılamadı ancak tüm hastalarda spot idrar protein/kreatinin oranı hesaplandı ve bu nedenle hastalarda proteinürinin değerlendirilmesi bu parametre üzerinden yapıldı. Steroide duyarlı NS hasta grubunda tanı anında spot idrar protein/kreatinin oranı 7,57 $\pm 4,53$ iken, SBNS hasta grubunda $12,39 \pm 6,27$ olarak tespit edildi. Steroid bağımlılığı geliştiren hastalarla, geliştirmeyen hastalar karşılaştırıldığında başlangıç kan albümin değerleri açısından anlamlı fark göstermezken SBNS hastalarının başlangıç proteinüri değerleri daha yüksekti $(p=0,014)$. Bir diğer parametre olan başlangıç kan beyaz küre seviyeleri SBNS hasta grubunda anlamlı olarak daha yüksekti $(p=0,004)$. Çalışmaya alınan hastaların karşılaştırıldığı son parametre ise steroid tedavisi başlanmasını takiben remisyona girme süreleriydi. Steroide duyarlı NS hastaları tedavi sonrası ortalama 9 günde remisyona girerken SBNS hastalarında bu süre ortalama 17,5 gündü ( $p=0,0001)$. Hastaların karşılaştırmalı verileri Tablo 1'de özetlenmiştir.

\section{TARTIŞMA}

İdiyopatik NS ile takip edilen çocuk hastalarda steroid bağımIılığının gelişmesi takip ve tedavide aile ve klinisyeni zorlayan önemli bir konudur. Bu hastalarda uzun dönem yüksek doz steroid tedavisine bağlı yan etki görülme riski yüksektir. İdiyopatik NS tanısı alan hastalarda steroid bağımlılığını tedavi başlangıcında işaret edebilecek ipuçları, bu hastalarda daha erken dönemde steroidden ayırıcı tedaviler başlanmasında ve steroid ilişkili yan etkilerin azaltılmasında faydalı olabilir.

Çalışmamızda SDNS hastalarında \%40 oranında seyreden steroid bağımlıı̆ı̆ literatürde bildirilen inS hastalarında \%22-61 arasında değişmektedir $(5,6)$. Bu geniş aralık çalışmaya dahil edilen hasta gruplarının değişkenliği, tedavide kullanılan steroid rejimlerine bağı olabilir. Çalışmamızda SDNS olup SBNS olarak seyreden ve seyretmeyen hastalarımızı cinsiyet ve hastalık başlangıç yaşları açısından karşılaştırdığımızda anlamlı fark görülmedi. Steroid bağımlılığı ve/veya sık relaps üzerinde cinsiyet ve hastalık başlangıç yaşının değerlendirildiği çalışmalarda karşıt sonuçlar mevcuttur. Andersen ve ark. (7) erkek cinsiyetin steroid bağımlılığı ve sık relaps üzerinde bir risk faktörü olduğunu belirtmiştir, ancak risk üzerindeki erkek cinsiyet baskınlığı erkeklerde artmış inS insidansı ile ilişkili olabilir. Bununla birlikte yine bu çalışma erken tanı yaşının da steroid bağımlılığında bir risk faktörü olduğunu belirtmektedir. Kabuki ve ark. (8) ise steroid bağımlıığının yaş ile birlikte arttığını belirtmişlerdir. Çalışmamız steroid bağımlılığının yaş ve cinsiyetten bağımsız olduğunu belirten Abdel-Hafez ve ark. (9)'nın çalışmasıyla uyumlu görünmektedir. Çalışmamızda steroid bağımlıı̆ı̆ını öngörmede karşılaştırılan diğer parametrelerden ikisi başvuru anında kan kreatinin ve albümin seviyeleriydi. Steroid bağımlı NS olan ve olmayan grupta başlangıç kan kreatinin ve albümin değerlerinde anlamlı fark gösterilmedi. Bu açıdan değerlendirildiğinde çalışmamızın sonuçları Daksyani ve ark. (10)'nın sonuçları ile uyumluydu. Ancak SBNS olan ve olmayan hastalar başvuru proteinüri değerleri açısından karşılaştırıldığında SBNS olan hastalarda başvuruda proteinürinin anlamlı şekilde yüksek olduğu görüldü. Abdel-Hafez ve ark. (9)'nın yapmış olduğu çaış̧mada başlangıç proteinüri düzeyi steroid bağımlılığında bir risk faktörü olarak bulunmamıştır. Çalışmamızda SBNS olan ve olmayan grupta anlamlı proteinüriye eşlik eden anlamlı albümin düşüklüğü beklenirken sonuçlarımız bu yönde değildi. Bu durum SBNS grubunda hastaların erken başvurusu ile açıklanabilir. Çalışmamızda değerlendirdiğimiz diğer bir parametre ise başvuru anında total beyaz küre, lenfosit ve beyaz küre/lenfosit oranlarıydı. Steroid bağımlı NS gelişen hastalarda başvuruda beyaz küre sayısının anlamlı olarak yüksek olduğunu ancak SBNS olan ve olmayan gruplar arasında lenfosit ve beyaz küre/lenfosit oranları arasında anlamlı fark olmadığı görüldü. Literatürde steroid bağımlılığını öngörmede bu parametreleri karşılaştıran bir çalışma görülmedi. Rai ve ark. (11) 2-10 yaş arası NS tanılı hastalarda steroid tedavisine erken ve geç yanıt veren hastaları değerlendirdikleri bir çalışmada, başlangıç CD4+ T lenfosit sayısı, yüzdesi ve tedavi ile CD4+ T lenfosit (\%) artışını steroide erken ve geç yanıt veren hastalarda karşılaştırmışlardır. Bu çaIışmada steroid tedavisine erken yanıtlı olan hastalarda $(<10$ gün) CD4+ T hücre (\%) ve artş̧ istatistiksel anlamlı bulunmuştur.

Nefrotik sendromda başta ÜSYE olmak üzere enfeksiyonların relapsı tetiklediği bilinmektedir. Enfeksiyonların relaps ile sonuçlanmasındaki patogenez net olarak bilinmemekle birlikte bu durumun T hücre upregülasyonu ve sitokin salınımıyla ilişkili olduğu düşünülmektedir $(9,12)$. Takahashi ve ark. (13) relaps sırasında eş zamanlı ÜSYE'nin sık relaps ve SBNS'de bir risk faktörü olduğunu belirtmiştir. Bu çalışmaya farklı bir açıdan bakıldığında NS'de ilk atağın enfeksiyon ile tetiklenmesinin de hastalık seyrinde SBNS gelişmesinde risk faktörü olabileceği söylenebilir. Çalışmamızda SBNS olarak seyreden ve seyretmeyen hastalar ilk ataklarında atak başlatıcısının olup olmamasına göre değerlendirildiğinde SBNS hastalarında öykü ve fizik muayene bulguları ile anlamlı şekilde atak başlatıcının olduğu görüldü. Steroid bağımlı NS olarak seyreden hastalarda başvuru beyaz küre sayısının da anlamlı yüksek olması bu sonucu desteklemektedir. Tetikleyici faktörler değerlendirildiğinde ise en sık etken ÜSYE idi.

Illk atak NS'de steroid tedavisi başlanmasını takiben geç remisyon görülmesi SBNS için bir risk faktörü olarak literatürdeki birçok çalışma ile desteklenmiştir. Letavernier ve ark. (14) tedavi başlanmasını takiben 20 gün içerisinde remisyona girmeyen hastalarda SBNS gelişme riskini anlamlı derece yüksek bulmuşlardır. Çalışmamızda SBNS gelişen hastaların daha uzun sürede remisyona girdiği görüldü. Sonuçlarımız bu açıdan literatür ile uyumlu bulundu. 
Sık relaps ve SBNS hastalarında hastalığı kontrol altında tutmayı sağlayan birikimli steroid dozu yüksektir, ancak iNS'de hastalık aktivitesinin zamanla azaldığı, en ağır SBNS hastalarının genellikle 5 yaş altında olduğu düşünülürse bu dönemde steroid ayırıcı tedavilerde gecikme olmaması ile steroide maruz kalma ve tedavinin toksik etkileri mümkün olan en düşük düzeyde tutulabilir $(15,16)$.

Sonuç olarak iNS'de ÜSYE ile ilk atağın tetiklenmesi, başvuru anında ağır proteinüri saptanması, steroid tedavisi başlanmasını takiben geç remisyon gözlenmesi hastalık seyrinde SBNS gelişmesine ilişkin risk faktörleri olabilir. Steroid ayırıcı tedavilerin daha erken gündeme alınması, steroid tedavisinin istenmeyen uzun dönem yan etkilerinden koruyacaktır.

Etik Komite Onayı: Bu çalışma için etik komite onayı Yerel Etik Kurul'dan alınmıştı. (tarih 24/09/2020 toplant no:11/no:15)

Bilgilendirilmiş Onam: Katlımcılardan bilgilendirilmiş onam alınmıştır.

Hakem Değerlendirmesi: Dış bağımsız.

Yazar Katkıları: Çalışma Konsepti/Tasarım- A.T.; Veri Toplama- A.T.; Veri Analizi/Yorumlama-N.Ç.; Yazı Taslağı- A.T.; İçeriğin Eleştirel İncelemesiN.Ç.; Son Onay ve Sorumluluk- A.T., N.Ç.; Malzeme ve Teknik DestekA.T.; Süpervizyon- A.T.

Çıkar Çatışması: Yazarlar çıkar çatş̧ması beyan etmemişlerdir.

Finansal Destek: Yazarlar finansal destek beyan etmemişlerdir.

Ethics Committee Approval: : Ethics committee approval was received for this study from the ethics committee of Local Ethics Committee. (date 24/09/2020 meeting no:11/no:15)

Informed Consent: Written consent was obtained from the participants.

Peer Review: Externally peer-reviewed.

Author Contributions: Conception/Design of Study- A.T.; Data Acquisition- A.T.; Data Analysis/Interpretation- N.Ç.; Drafting Manuscript- A.T.; Critical Revision of Manuscript- N.Ç.; Final Approval and Accountability- A.T., N.Ç.; Technical or Material Support- A.T.; Supervision- A.T.

Conflict of Interest: Authors declared no conflict of interest.

Financial Disclosure: Authors declared no financial support.

\section{KAYNAKLAR/REFERENCES}

1. Eddy AA, Symons JM. Nephrotic syndrome in childhood. Lancet 2003 Aug 23;362(9384):629-39.
2. Niaudet $\mathrm{P}, \mathrm{Boyer} \mathrm{O}$. Idiopathic nephrotic syndrome in children: Clinical aspects in a textbook of pediatric nephrology. In: Avner D et al. (eds). 7th ed; 2016. pp. 839-82.

3. Kang HG, Cheong HI. Nephrotic syndrome: what's new, what's hot? Korean J Pediatr 2015 Aug;58(8):275-82.

4. Gipson DS, Massengill SF, Yao L, Nagaraj S, Smoyer WE, Mahan JD, et al. Management of childhood onset nephrotic syndrome. Pediatrics 2009 Aug;124(2):747-57.

5. Park SJ, Shin Jl. Complications of nephrotic syndrome. Korean J Pediatr 2011 Aug;54(8):322-8.

6. Sinha A, Hari P, Sharma PK, Gulati A, Kalaivani M, Mantan M, et al. Disease course in steroid sensitive nephrotic syndrome. Indian Pediatr 2012 Nov;49(11):881-7.

7. Dawman L, Mehta A, Sharawat IK, Yadav R. Risk factors for steroid dependency in children with idiopathic nephrotic syndrome in India. Indian J Pediatr 2016 Mar;83(3):261.

8. Andersen RF, Thrane N, Noergaard K, Rytter L, Jespersen B, Rittig S. Early age at debut is a predictor of steroid-dependant and frequently relapsing nephrotic syndrome. Pediatr Nephrol 2010 Jul;25(7):1299-304.

9. Kabuki N, Okugawa T, Hayakawa H, Tomizawa S, Kasahara T, Uchiyama M. Influence of age at onset on the outcome of steroid-sensitive nephrotic syndrome. Pediatr Nephrol 1998 Aug;12(6):467-70.

10. Abdel-Hafez MA, Abou-El-Hana NM, Erfan AA, El-Gamasy M, AbdelNabi H. Predictive risk factors of steroid-dependent nephrotic syndrome in children. J Nephropathol 2017Jul;6(3):180-6.

11. Dakshayani B, Lakshmanna M, Premalatha R. Predictors of frequent relapsing and steroid-dependent nephrotic syndrome in children. Turk Pediatri Ars 2018 Mar 1;53(1):24-30.

12. Rai VK, Awasthi S, Venkatesh V. Prediction of early response to steroids in nephrotic syndrome patients aged between 2 and 10 years. Clin Epidem and Glob Health 2017 Dec;5(4):203-8.

13. MacDonald NE, Wolfish N, McLaine P, Phipps P, Rossier E. Role of respiratory viruses in exacerbations of primary nephrotic syndrome. J Pediatr 1986 Mar;108(3):378-82.

14. Takahashi S, Wada N, Murakami H, Funaki S, Inagaki T, Harada K, et al. Triggers of relapse in steroid-dependent and frequently relapsing nephrotic syndrome. Pediatr Nephrol 2007 Feb;22(2):232-6.

15. Letavernier B, Letavernier $E$, Leroy $S$, Baudet-Bonneville $V$, Bensman A, Ulinski T. Prediction of high-degree steroid dependency in pediatric idiopathic nephrotic syndrome. Pediatr Nephrol 2008 Dec;23(12):2221-6.

16. Niaudet P. Long-Term outcome of children with steroid-sensitive idiopathic nephrotic syndrome. Clin J Am Soc Nephrol 2009 Oct;4(10):1547-8.

17. Fakhouri F, Bocquet N, Taupin P, Presne C, Gagnadoux MF, Landais $P$, et al. Steroid-sensitive nephrotic syndrome: from childhood to adulthood. Am J Kidney Dis 2003 Mar;41(3):550-7. 